\title{
ANALISIS VEGETASI PERINTIS LOKAL DI LAHAN BEKAS TAMBANG PASIR KECAMATAN CIMALAKA KABUPATEN SUMEDANG
}

\author{
Analysis of Local Pioneer Vegetation in the Former Sand Mine Land in Cimalaka \\ District, Sumedang Regency
}

Raizal Fahmi Solihat

Fakultas Kehutanan Universitas Winaya Mukti; Jl. Raya Bandung-Sumedang Km. 29

Tanjungsari-Sumedang 45362, (022) 87918051

e-mail: raizal.fahmi@gmail.com

Diterima : 04/02/2020, Direvisi : 14/01/2022, Disetujui : 17/01/2022

\begin{abstract}
Mining activities generally use large tracts of land, utilize non-renewable resources, produce a lot of waste, and make land degraded and unproductive. This happened on one of the former sand mining areas in Cimalaka sub-district, Sumedang Regency. Rehabilitation techniques by planting pioneering plants known as swapping are effective techniques. Pioneer plants are plants that start the formation of a habitat. This study aims to obtain information about the structure and composition of pioneering plants in the former sand mining quarry in the Cimalaka sub-district of Sumedang Regency. This research is descriptive, using a survey method with exploration, the research sample is a local pioneering plant that is included in the sampling plot found at the research location. The results showed that the structure at the level of pioneering vegetation in the former sand fields of Cimalaka subdistrict, namely shrubs Eleusine indica L. and Axonopus compressus, seedling plant Calliandra calothyrsus, Gliricidia sepium, Ageratum conyzoides L. Imperata cylindrica L. Saccharum spontaneum L. Vetiveria zizanioides Stapf. dan Coleus soutellarioides $L$.
\end{abstract}

Keywords: vegetation, pioneer plant, land rehabilitation

\section{ABSTRAK}

Kegiatan penambangan umumnya menggunakan lahan luas, memanfaatkan sumberdaya tak terbarukan, menghasilkan banyak limbah, serta menjadikan lahan terdegradasi dan tidak produktif. Hal ini terjadi pada salah satu lahan bekas tambang pasir di kecamatan Cimalaka Kabupaten Sumedang. Teknik rehabilitasi dengan penanaman tumbuhan perintis yang dikenal dengan pembelukaran merupakan teknik yang efektif. Tumbuhan perintis merupakan tumbuhan yang mengawali terbentuknya suatu habitat. Penelitian ini bertujuan untuk mendapatkan informasi tentang struktur dan komposisi tumbuhan perintis pada lahan bekas tambang galian pasir di kecamatan Cimalaka Kabupaten Sumedang. Penelitian ini bersifat deskriptif, menggunakan metode survey dengan eksplorasi, sampel penelitian merupakan tumbuhan perintis lokal yang masuk kedalam plot sampling yang ditemukan ditempat lokasi penelitian. Hasil menunjukkan bahwa struktur pada tingkat vegetasi perintis di 
lahan bekas galian pasir kecamatan Cimalaka yaitu tumbuhan bawah Eleusine indica L. dan Axonopus compressus, tumbuhan semai Calliandra calothyrsus, Gliricidia sepium, Ageratum conyzoides L. Imperata cylindrica L. Saccharum spontaneum L. Vetiveria zizanioides Stapf. dan Coleus soutellarioides $L$.

Kata kunci: Vegetasi, tumbuhan perintis, rehabilitasi lahan

\section{PENDAHULUAN}

Usaha pertambangan pasir dapat memberikan manfaat ekonomi bagi masyarakat yang berkerja di bidang tersebut. Di Kendal Jawa Tengah, aktivitas pertambangan pasir oleh masyarakat dilakukan karena pendapatan dari hasil tambang dapat diperoleh setiap saat dengan jam kerja yang tidak mengikat. Berbeda dengan bekerja sebagai petani yang memanen hanya pada saat-saat tertentu dengan jam kerja tertentu pula (Maulidah \& Brata, 2018).

Selain memberi keuntungan secara ekonomi bagi masyarakat sekitar, penambangan pasir bila tidak dikelola sesuai kaidah pengelolaan lingkungan yang benar, akan memiliki dampak negatif terutama terhadap lingkungan dan tanah. Hasil penelitian Suherman et al. (2015) menunjukkan terdapat peningkatan kemiringan lereng sebagai dampak penambangan pasir di Tasikmalaya yang menaikkan tingkat bahaya erosi (TBE). Herniti \& Kiky (2018) melaporkan dampak penambangan pasir terhadap tanah di Sleman menyebabkan penurunan kesuburan tanah, penurunan jumlah mikroorganisme tanah dan penurunan permeabilitas tanah. Untuk mengembalikan kondisi ekosistem tanah karena terjadi penurunan produktivitas tanah maka dibutuhkan vegetasi pionir atau vegetasi perintis.

Munculnya vegetasi perintis pada lahan bekas tambang menunjukkan ada keberhasilan proses suksesi dan dapat dipercepat dengan kegiatan rehabilitasi. Vegetasi perintis merupakan tumbuhan yang mengawali terbentuknya suatu habitat. Fajri \& Garsetiasih (2019) pada bekas tambang galian C di Berau menemukan komposisi spesies pionir Leea guineensis, Leucaena leucocephala, Croton sp, Piper aduncum, Macaranga conifera, Ficus sp, Callicarpa pentandra dan Leucaena leucocephala dengan indeks keragaman jenis vegetasi yang sedang. Suksesi alam yang terjadi telah menyebabkan perubahan iklim mikro yang lebih baik dan peningkatkan kualitas dan produktivitas tanah. Menurut Ramdhan (2009) terjadinya perubahanperubahan pada populasi mendorong perubahan pada komunitas. yang menyebabkan ekosistem berubah. Perubahan ekosistem akan berakhir setelah terjadi keseimbangan ekosistem (homeostatis). Keadaan tersebut merupakan klimaks dari ekosistem.

Wilayah Sumedang terdapat lebih dari 300 hektare hamparan lahan kritis dan gersang akibat galian pasir (galian tipe C) yang harus dikelola dengan tepat agar mempunyai nilai tambah dan tidak menjadi bencana lingkungan yang merugikan.

Aktivitas masyarakat dan warga sekitar yang memanfaatkan potensi Tampomas masih tetap berlanjut. Salah satu aktivitas masyarakat di sekitar gunung Tampomas adalah melakukan penambangan galian-C. Pertambangan galian-C banyak ditemukan di Kecamatan Cimalaka, Paseh dan Conggeang di kaki dan lereng gunung Tampomas yang terus dieksplorasi sejak tahun 2000. Penggunaan lahan untuk area pertambangan galian- $C$ di Sumedang mengalami peningkatan rata-rata 38 hektar $(0,14 \%)$ per tahun. Tingkat perubahan per tahun dari luas pertambangan galian- $C$ tergolong pada kelas tinggi, karena telah melampaui luas perubahan per tahun maksimal yakni sekitar 0,05\% (Junaedi, 2008).

Ardhana (2012 dalam Nursyahra dkk., 2016) menjelaskan bahwa vegetasi adalah suatu kelompok atau suatu kumpulan komunitas tumbuhan yang terdiri dari beberapa jenis yang hidup bersama-sama pada suatu tempat dan saling berinteraksi. Sedangkan yang dimaksud dengan vegetasi dasar adalah lapisan tumbuhan penutup tanah yang biasa terdiri dari herba, 
semak, liana dan paku-pakuan. Vegetasi dasa banyak ditemukan pada habitat yang rusak, sehingga termasuk jenis tumbuhan pionir, hal ini bisa terjadi pada lahan bekas pertambangan.

Sehubungan dengan hal tersebut di atas maka penelitian ini bertujuan untuk mendapatkan informasi tentang struktur dan komposisi vegetasi pada lahan bekas tambang yang telah tumbuh tumbuhan perintis di lahan bekas tambang galian pasir Kecamatan Cimalaka Kabupaten Sumedang yang diharapkan bisa dijadikan sebagai pertimbangan dalam penentuan jenis tumbuhan dalam kegiatan reklamasi lahan bekas tambang galian pasir dan batu atau galian pasir.

\section{METODE}

\section{A. Lokasi Penelitian}

Kawasan Cimalaka, di kaki gunung Tampomas, dari luas penambangan pasir sekitar 250 ha, hampir 215 ha bukit yang dulu hijau telah menjadi cekungan raksasa dan hamparan batu kerikil. Tanah menjadi gersang, berdebu, udara terasa panas di lokasi padang pasir bekas galian masuk dalam wilayah Desa Cibeureum Kulon

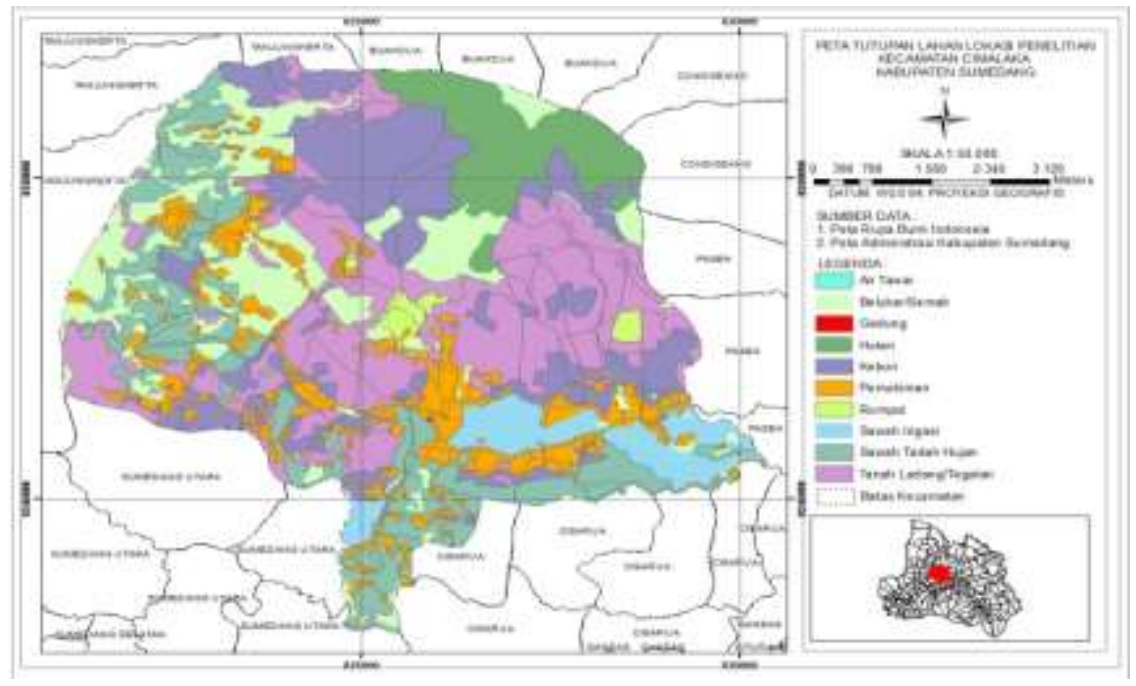

Gambar 1.Peta Lokasi Penelitian

Figure 1. Research Location Map

\section{B. Bahan dan Alat Penelitian}

Bahan yang digunakan dalam penelitian ini adalah sampel tumbuhan perintis dan media tumbuh/tanah sedangkan alat yang digunakan laptop, meteran1 rol, tali tambang100 m, kamera digital 1 unit, alat tulis 1 paket, parang, GPS 2 unit, peta tutupan lahan dan bor tanah

\section{Metode Pengambilan Sampling}

Jenis penelitian ini bersifat deskriptif, menggunakan metode survey dengan eksplorasi yaitu segala cara untuk menetapkan lebih teliti atau seksama dalam suatu penelitian dan dokumentasi. Penelitian dilaksanakan selama empat bulan, lokasi penelitian terletak di lahan bekas pertambangan galian pasir yang berada di Kecamatan Cimalaka kabupaten Sumedang.

Sampel dalam penelitian ini yaitu tumbuhan perintis lokal yang masuk kedalam plot sampling yang ditemukan ditempat lokasi penelitian yaitu di lahan bekas tambang galian pasir 
kecamatan Cimalaka. Kabupaten Sumedang. Pengambilan data primer dilakukan dengan cara sebagai berikut :

1. Penentuan lokasi pengambilan contoh/sampel

Metode yang digunakan untuk pengumpulan dan pengambilan sampel dengan menggunakan teknik porpusive sampling yang dilakukan dengan cara menempatkan plot sampling pada lahan bekas tambang yang sudah tumbuh vegetasi perintis.

2. Penentuan Bentuk Satuan Contoh

Bentuk satuan contoh atau plot merujuk pada teori KSA (Kurva Spesies Area) yaitu dengan menentukan luas minimum area denan cara pembuatan plot dimulai dengan ukuran $2 \times 2 \mathrm{~m}^{2}$ kemudian ditambah ukurannya menjadi $4 \times 4 \mathrm{~m}^{2}$ apabila pada plot ukuran $4 \times 4 \mathrm{~m}^{2}$ ditemukan jenis yang baru maka ditambah lagi ukurannya dengan penambahan $2 \mathrm{~m}^{2}$ menjadi $6 \times 6 \mathrm{~m}^{2}$ dan seterusnya sampai tidak ditemukan lagi jenis yang baru pada plot berikutnya .

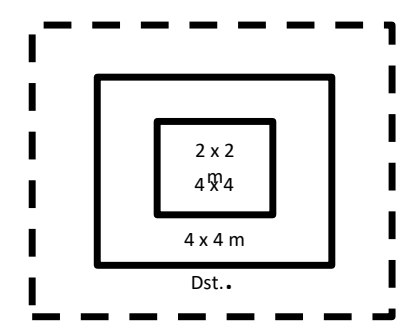

Kemudian dilakukan kembali menempatkan plot baru $2 \times 2 \mathrm{~m}^{2}$ pada lokasi yang memiliki vegetasi tumbuhan perintis berikutnya.

3. Pengambilan Sampel Tumbuhan Perintis dan contoh Tanah

Untuk sampel tumbuhan perintis dalam penelitian ini yaitu setiap jenis tumbuhan perintis yang ditemukan difoto dan diambil satu spesimen untuk diidentifikasi.

\section{Analisis Data}

Data vegetasi yang telah terkumpul kemudian dianalisis untuk mengetahui kerapatan jenis, kerapatan relatif, dominansi jenis, dominansi relatif, frekuensi jenis dan frekuensi relatif serta Indeks Nilai Penting menggunakan rumus sebagai berikut:

$$
\begin{aligned}
& \text { Kerapatan jenis }(\mathrm{K}) \quad \frac{\text { Jumlah individu suatu jenis }}{\text { Luas total petak contoh }} \\
& \text { K. Relatif }(\mathrm{KR})=\frac{\text { K suatu jenis }}{\text { K total seluruh jenis }} \times 100 \% \\
& \text { Dominansi }(\mathrm{D})=\frac{\text { Luas penutupan suatu jenis }}{\text { Luas petak contoh }} \\
& \text { D. Relatif }(\mathrm{DR})=\frac{\text { D suatu jenis } x 100 \%}{\text { D seluruh jenis }} \\
& \text { Frekuensi }(\mathrm{F}) \quad \frac{\text { Jumlah petak yang diduduki jenis }}{\text { Jumlah seluruh petak contoh }}= \\
& \frac{\text { F suatu jenis } x \text { seluruh jenis }}{\text { F }}
\end{aligned}
$$


Indeks Nilai Penting atau INP $=$ KR + DR + FR Nilai penting merupakan penjumlahan dari kerapatan relatif, frekuensi relative dan dominansi relatif yang berkisar antara 0 sampai 300 .

\section{HASIL DAN PEMBAHASAN}

\section{A. Gambaran Umum Lokasi}

Kegiatan penambangan pada umumnya terdiri dari beberapa tahapan, yaitu tahap persiapan, tahap eksploitasi dan tahap reklamasi atau rehabilitasi lahan pasca penambangan. 1). Tahap persiapan, diantaranya yaitu kegiatan pengangkutan berbagai jenis peralatan tambang, pembukaan lahan (land-learing) dan pembuatan atau pembukaan jalan tambang. 2). Tahap eksploitasi, adalah kegiatan utama yang dilakukan yaitu penambangan atau penggalian bahan tambang dengan jenis dan keterdapatan bahan tambang yang berbeda-beda. 3). Tahap reklamasi, bertujuan untuk memperbaiki lahan bekas tambang agar kondisinya aman, stabil dan tidak mudah tererosi sehingga dapat dimanfaatkan kembali. Reklamasi sebaiknya dilakukan dengan cepat pada lahan bekas penambangan yang telah dieksploitasi, meskipun kegiatan penambangan tersebut secara keseluruhan belum selesai karena masih terdapat bahan tambang yang belum ditambang (Kusuma, 2009).

Kawasan Cimalaka, di kaki gunung Tampomas, dari luas penambangan pasir sekitar 250 hektare, hampir 215 hektare

\section{B. Struktur dan Komposisi Jenis}

Tabel 1. Taksonomi dan total jumlah tumbuhan perintis di lahan bekas galian pasir gunung tampomas

Table 1. Taxonomy and total number of pioneer plants in former tampomas mountain sand excavation

\begin{tabular}{|c|c|c|c|c|}
\hline No & Famili & Genus & Spesies & $\begin{array}{l}\text { Jumlah tota } \\
\text { individu }\end{array}$ \\
\hline 1 & Fabaceae & Calliandra & $\begin{array}{ll}\text { Kaliandra } & \text { (Calliandra } \\
\text { calothyrsus) }\end{array}$ & 265 \\
\hline 2 & & Gliricidia & $\begin{array}{l}\text { Cebreng/gamal } \\
\text { (Gliricidia sepium) }\end{array}$ & 134 \\
\hline 3 & Compositeae & Ageratum & $\begin{array}{l}\text { Bandotan (Ageratum } \\
\text { conyzoides L.) }\end{array}$ & 333 \\
\hline 4 & Poaseae & Eleusine & $\begin{array}{l}\text { Jampang (Eleusine } \\
\text { indica L.) }\end{array}$ & 288 \\
\hline 5 & & Imperata & $\begin{array}{l}\text { Alang-alang (Imperata } \\
\text { cylindrica L.) }\end{array}$ & 586 \\
\hline 6 & & Saccharum & $\begin{array}{l}\text { Gelagah (Saccharum } \\
\text { spontaneum L.) }\end{array}$ & 438 \\
\hline 7 & & Axonopus & $\begin{array}{l}\text { Rumput gajah/paitan } \\
\text { (Axonopus compressus) }\end{array}$ & 145 \\
\hline 8 & Graminae & Graminales & $\begin{array}{l}\text { Akar wangi (Vetiveria } \\
\text { zizanioides Stapf) }\end{array}$ & 87 \\
\hline 9 & Lamiaceae & Solenostemon & $\begin{array}{l}\text { Jawer kotok (Coleus } \\
\text { soutellarioides L.) }\end{array}$ & 48 \\
\hline & Total & & & 2334 \\
\hline
\end{tabular}


Hasil pengamatan taksonomi, terdapat 9 spesies dan genus dari 5 famili. Jumlah terbanyak yang didapatkan yaitu dari family Poaseae dengan 4 spesies dan dari family Fabaceae 2 spesies.

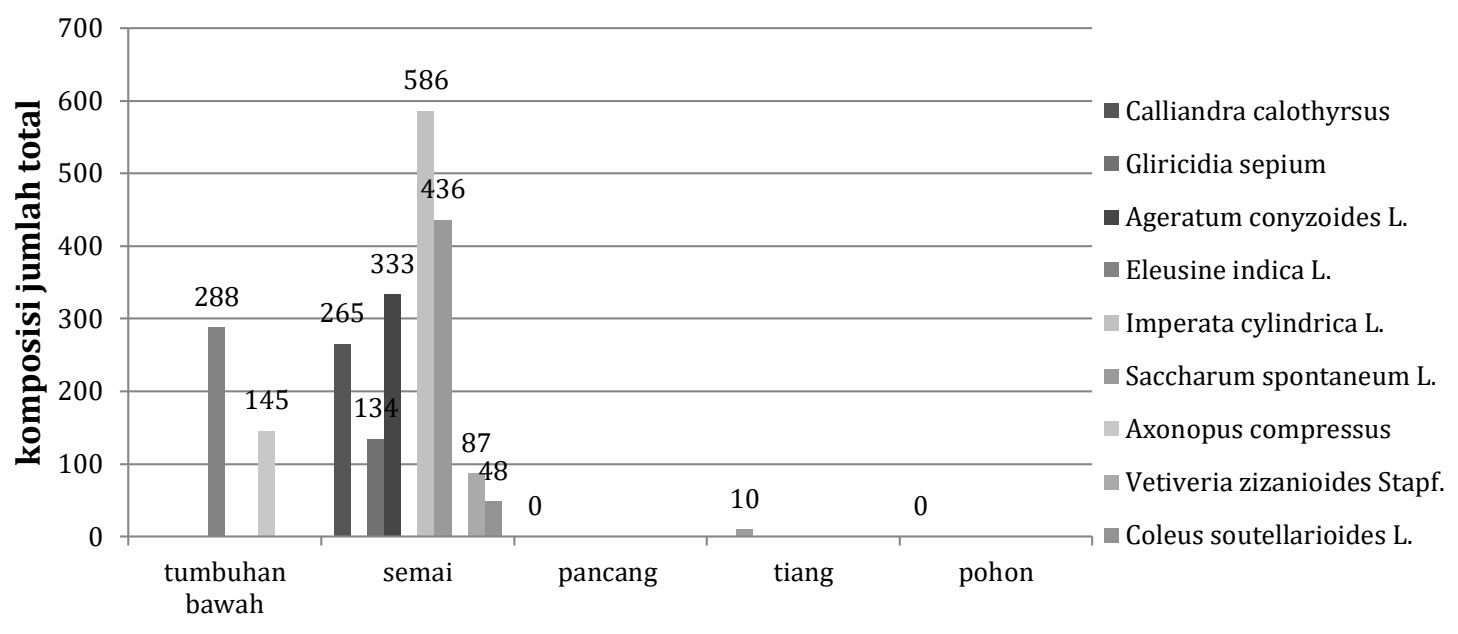

Struktur vegetasi

Gambar 2. Struktur dan komposisi jenis tumbuhan perintis di lahan bekas galian pasir gunung tampomas

Figure 2. Structure and composition of pioneer plant species in the former sand fields of Tampomas Mountain

Struktur tingkatan tumbuhan pada lahan galian pasir di tampomas terdiri dari tumbuhan bawah (Eleusine indica L. dan Axonopus compressus), semai (Calliandra calothyrsus, Gliricidia sepium, Ageratum conyzoides L. Imperata cylindrica L. Saccharum spontaneum L. Vetiveria zizanioides Stapf. dan Coleus soutellarioides L.) Pada tingkat pancang dan pohon tidak ditemukan pada lokasi penelitian.

Tabel 2. Vegetasi tumbuhan perintis pada setiap ketinggian di lahan bekas galian pasir gunung tampomas

Table 2. Vegetation of pioneer plants at every height in the former sand soil of tampomas mountain

\begin{tabular}{|c|c|c|c|c|c|c|c|}
\hline \multirow[t]{2}{*}{ No } & \multirow[b]{2}{*}{ Spesies } & \multicolumn{5}{|c|}{ Ketinggian tempat } & \multirow[b]{2}{*}{$\begin{array}{l}788 \\
\text { m.dpl }\end{array}$} \\
\hline & & $\begin{array}{l}606 \\
\text { m.dpl }\end{array}$ & $\begin{array}{l}664 \\
\text { m.dpl }\end{array}$ & $\begin{array}{l}666 \\
\text { m.dpl }\end{array}$ & $\begin{array}{l}670 \\
\text { m.dpl }\end{array}$ & $\begin{array}{l}671 \\
\text { m.dpl }\end{array}$ & \\
\hline 1 & Kaliandra (Calliandra calothyrsus) & & $\sqrt{ }$ & $\sqrt{ }$ & $\sqrt{ }$ & $\sqrt{ }$ & $\sqrt{ }$ \\
\hline 2 & Cebreng/gamal (Gliricidia sepium) & $\sqrt{ }$ & & & & & \\
\hline 3 & $\begin{array}{l}\text { Bandotan (Ageratum conyzoides } \\
\text { L.) }\end{array}$ & & & & & $\sqrt{ }$ & \\
\hline 4 & Jampang (Eleusine indica L. ) & & $\sqrt{ }$ & $\sqrt{ }$ & & $\sqrt{ }$ & $\sqrt{ }$ \\
\hline 5 & $\begin{array}{l}\text { Alang-alang (Imperata cylindrica } \\
\text { L.) }\end{array}$ & & & $\sqrt{ }$ & & $\sqrt{ }$ & $\sqrt{ }$ \\
\hline 6 & $\begin{array}{l}\text { Gelagah (Saccharum spontaneum } \\
\text { L.) }\end{array}$ & & & & & & $\sqrt{ }$ \\
\hline 7 & $\begin{array}{l}\text { Rumput gajah/paitan (Axonopus } \\
\text { compressus) }\end{array}$ & & & & & & $\sqrt{ }$ \\
\hline 8 & Akar wangi (Vetiveria zizanioides & & & & & & $\sqrt{ }$ \\
\hline
\end{tabular}




\section{$9 \begin{array}{ll}\text { Stapf) } \\ \text { Jawer kotok (Coleus }\end{array}$ soutellarioides L.)}

Titik koordinat yang diambil dalam mengambil semple tumbuhan perintis ialah pada ketinggian $606 \mathrm{~m}$. dpl sampai $788 \mathrm{~m}$. dpl. Hal ini berdasrkan pada lokasi lahan bekas galian pasir yang berada sepanjang titik koorditan tersebut. Pada setiap ketinggian, tumbuhan yang ditemuakn beragam dan beberapa jenis tumbuhan ditemukan pada ketinggian yang sama.

Kawasan penelitian di gunung tampomas dibagi ke dalam tiga wilayah. Pertama di wilayah ciberem wetan, ke dua di wilayah ciberem kulon dan terakhir di wilayah cililin.

Tabel 3. Kepadatan vegetasi tumbuhan perintis dilahan bekas galian pasir gunung tampomas di wilayah ciberem wetan

Table 3. Density of pioneering vegetation in ex-tampomas mountain sand mines in the Ciberem Wetan area

\begin{tabular}{clcccc}
\hline No & Spesies & Jumlah & KR (\%) & FR (\%) & INP \\
\hline 1 & Kaliandra (Calliandra calothyrsus) & 73 & 10 & 20 & 30 \\
3 & Bandotan (Ageratum conyzoides L.) & 108 & 15 & 15 & 30 \\
4 & Jampang (Eleusine indica L. ) & 93 & 13 & 13 & 26 \\
5 & Alang-alang (Imperata cylindrica L.) & 154 & 21 & 20 & 41 \\
6 & Gelagah (Saccharum spontaneum L.) & 167 & 23 & 14 & 37 \\
7 & Rumput gajah/paitan (Axonopus compressus) & 29 & 4 & 4 & 8 \\
8 & Akar wangi (Vetiveria zizanioides Stapf.) & 72 & 10 & 10 & 20 \\
9 & Jawer kotok (Coleus soutellarioides L.) & 28 & 4 & 4 & 8 \\
\hline
\end{tabular}

Terdapat 9 spesies yang ditemukan di wilayah ini, jumlah terbanyak yaitu dari tumbuhan Gelagah (Saccharum spontaneum L.) sebanyak 167 individu dan jumlah terendah yaitu dari tumbuhan Sengon (Jawer kotok (Coleus soutellarioides L.).) sebanyak 29 individu.

Tabel 4. Kepadatan vegetasi tumbuhan perintis dilahan bekas galian pasir gunung tampomas di wilayah ciberem kulon

Table 4 Density of pioneering vegetation in ex-tampomas mountain sand in the ciberem kulon area

\begin{tabular}{cccccc}
\hline \multirow{2}{*}{ No } & \multirow{2}{*}{ Spesies } & Jumlah & $\mathbf{K R}(\%)$ & $\mathbf{F R ( \% )}$ & INP \\
& & & & & \\
\hline 1 & Kaliandra (Calliandra calothyrsus) & 35 & 14 & 21 & 35 \\
2 & Cebreng/gamal (Gliricidia sepium) & 5 & 7 & 12 \\
\hline
\end{tabular}




\begin{tabular}{|c|c|c|c|c|c|}
\hline 3 & Bandotan (Ageratum conyzoides L.) & 97 & 14 & 14 & 28 \\
\hline 4 & Jampang (Eleusine indica L. ) & 55 & 8 & 7 & 15 \\
\hline 5 & Alang-alang (Imperata cylindrica L.) & 193 & 28 & 18 & 46 \\
\hline 6 & Gelagah (Saccharum spontaneum L.) & 113 & 16 & 11 & 27 \\
\hline 7 & $\begin{array}{l}\text { Rumput gajah/paitan (Axonopus } \\
\text { compressus) }\end{array}$ & 67 & 10 & 11 & 21 \\
\hline 8 & Akar wangi (Vetiveria zizanioides Stapf.) & 15 & 2 & 7 & 9 \\
\hline 9 & Jawer kotok (Coleus soutellarioides L.) & 20 & 3 & 4 & 7 \\
\hline & Total & 690 & 100 & 100 & 200 \\
\hline
\end{tabular}

Wilayah cibereum kulon paling banyak terdapat alang-alang (Saccharum spontaneum L.) family poaseae sebanyak 193 individu. Dan paling sedikit ialah pada tumbuhan akar wangi (Vetiveria zizanioides Stapf.) dari family graminae sebnyak 15 individu. Spesies yang ditemukan di wilayah ini sebanyak 9 spesies.

Tabel 5. Kepadatan vegetasi tumbuhan perintis dilahan bekas galian pasir gunung tampomas di wilayah cililin

Table 5. Density of pioneering vegetation in ex-tampomas mountain sand mines in Cililin region

\begin{tabular}{|c|c|c|c|c|c|}
\hline No & Spesies & Jumlah & $\mathrm{KR}(\%)$ & $F R(\%)$ & INP \\
\hline 1 & Kaliandra (Calliandra calothyrsus) & 97 & 10 & 19 & 29 \\
\hline 2 & Cebreng/gamal (Gliricidia sepium) & 99 & 10 & 16 & 26 \\
\hline 3 & Bandotan (Ageratum conyzoides L.) & 128 & 13 & 13 & 26 \\
\hline 4 & Jampang (Eleusine indica L. ) & 140 & 15 & 13 & 28 \\
\hline 5 & Alang-alang (Imperata cylindrica L.) & 239 & 25 & 16 & 41 \\
\hline 6 & Gelagah (Saccharum spontaneum L.) & 158 & 17 & 13 & 30 \\
\hline 7 & $\begin{array}{l}\text { Rumput gajah/paitan (Axonopus } \\
\text { compressus) }\end{array}$ & 49 & 5 & 6 & 11 \\
\hline 8 & Jawer kotok (Coleus soutellarioides L.) & 39 & 5 & 4 & 9 \\
\hline & Total & 949 & 100 & 100 & 200 \\
\hline
\end{tabular}

Wilayah cililin tumbuhan perintis yang paling banyak ialah alang-alang (Imperata cylindrica L.) dari family poaseae sebanyak 239 individu. Sedangkan yang paling sedikit yaitu pada Jawer kotok (Coleus soutellarioides L.) dari family lamiaceae sebanyak 39 individu, pada wilayah ini paling sedikit spesies yang ditemukan. 
Berdasarkan hasil yang diperoleh dalam penelitian ini, terdapat empat tingkatan jenis tumbuhan yang ditemukan di lahan bekas galian pasir, (grafik 1.2) diantaranya tumbuhan bawah yaitu Eleusine indica L. dan Axonopus compressus dengan jumlah yang cukap banyak yaitu 288 dan 125 individu. Selanjutnya yang paling banyak ditemukan dengan jumlah individu yang banyak yaitu pada tingkat semai. Terdapat enam jenis tumbuhan diantaranya Calliandra calothyrsus (265 individu), Gliricidia sepium (134 individu), Ageratum conyzoides L (333 individu). Imperata cylindrica L. (586 individu). Saccharum spontaneum L. (438 indivudu). Vetiveria zizanioides Stapf. (87 individu) dan Coleus soutellarioides L. (48 individu). Jenis tumbuhan tiang paling sedikit ditemukan yaitu Akar wangi (Vetiveria zizanioides Stapf.). (15 individu)

\section{Keragaman Jenis}

Jenis tumbuhan perintis merupakan jenis-jenis tumbuhan yang pertama tumbuh pada kawasan yang tidak bervegetasi. Hasil penelitian pada (tabel 1.2) menunujukan jenis-jenis tumbuhan perintis yang berada di kawasan galian pasir gunung tampomas. Terdapat 9 spesies dan genus dari 5 famili. Jumlah total individu yang didapatkan adalah 2334, yang paling banyak jumlah individu yang didapatkan ialah pada tumbuhan Imperata cylindrica $L$. dari family poaceae sebanyak 586. Sedangkan yang paling sedikit jumlah individu yaitu pada tumbuhan Akar wangi (Vetiveria zizanioides Stapf.). (15 individu)

Imperata cylindrica $L$. atau disebut tumbuhan alang-alang dari family poaceae merupakan jenis yang paling banyak ditemukan, hal ini disebabkan tumbuhan alang-alang tumbuh pada lahan yang tingkat kesuburannya rendah, seperti halnya daerah pertambangan. F. Aulia dkk,. (2015) menjelaskan pada penelitiannya bahwa pada daerah pertambangan khususnya pada lahan yang telah terbengkalai lama tumbuhan yang mendominasi ialah tumbuhan alang-alang dan rumput liar. A. Pudjiharta dkk., (2008) menambahkan bahwa tumbuhan alang-alang merupakan jenis tumbuhan yang tidak memerlukan syarat yang rumit dalam pertumbuhannya dan dapat tumbuh pada kondisi tanah yang subur atau tanah yang tidak subur. Tumbuhan ini juga tidak memerlukan syarat iklim sehingga alang-alang dapat tumbuh pada daerah beriklim basah maupun kering.

Tabel (1.3) merupakan sebaran tumbuhan yang ditemukan pada ketinggian yang berbeda. Tumbuhan kaliandra atau Calliandra calothyrsus ditemukan disetiap ketinggian yang berbeda, hal ini menunjukan bahwa tumbuhan ini dapat beradaptasi pada kondisi dan tempat yang berbeda-beda. Tumbuhan perintis yang paling banyak ditemukan yaitu pada ketinggian $788 \mathrm{~m}$. dpl. Terdapat faktor yang mempengaruhi hal tersebut, fiantaranya yaitu ketersedian unsur hara yang mencukupi akan pertumbuhannya.

Indeks Nilai Penting Vegetasi Perintis

Terdepat tiga wilayah dalam menentukan vegetasi perintis pada kawasan bekas galian pasir. wilayah yang pertama yaitu dari Cibereum wetan (tabel 1. 4). Indeks nilai penting (INP) pada wilayah ini paling tinggi yaitu tumbuhan Paraserianthes falcataria $\mathrm{L}$. sebesar $5.04 \%$, dan yang paling rendah ialah pada tumbuhan Coleus soutellarioides L dan Axonopus compressus. sebesar $0.08 \%$. Wilayah kedua yaitu Cibereum kulon (tabel 1.5 ). Indeks nilai penting (INP) yang paling tinggi ialah pada tumbuhan Imperata cylindrica L. sebesar $0.46 \%$ dan yang paling rendah yaitu pada tumbuhan Coleus soutellarioides L. sebesar $0.07 \%$. Wilayah terakhir yaitu Cililin (tabel 1.6) dengan indeks paling tinggi yaitu pada tumbuhan Imperata cylindrica L. $0.41 \%$ sedangkan INP paling rendah yaitu pada tumbuhan Coleus soutellarioides $\mathrm{L} 0.07 \%$.

Soegianto (1994 dalam Ismaini, dkk., 2015) menjelaskan bahwa indeks nilai penting (INP) suatu jenis tumbuhan yang merupakan salah satu parameter peranan jenis tumbuhan tersebut dalam komunitasnya, hal ini diartikan sebagai kemampuan adaptasi dengan habitat dan toleransi terhadap kondisi lingkungan. Sehingga jika semakin tinggi nilai INP suatu spesies 
maka ekosistem tersebut akan setabil dan semakin besar tingkat penguasaan terhadap komunitas. Nilai INP tertinggi dari ketiga wilayah pengamatan merupakan tingkatan vegetasi pohon yaitu tumbuhan Paraserianthes falcataria $\mathrm{L}$.

Tumbuhan Paraserianthes falcataria L. merupakan jenis tumbuhan dari family fabaceae. Fabaceae merupakan jenis tumbuhan polong-polongan, menurut Lewis dkk.,(2005 dalam Agung, 2013) family fabaceae merupakan komponen mayor dari vegetasi dunia dan sering ditemui pada lahan marginal karena kemampuannya untuk memfiksasi nitrogen dari atmosfer melalui bintil akar. Sehingga jenis tumbuhan ini merupakan jenis tumbuhan yang dapat beradaptasi dengan habitatnya meskipun dalam kondisi lahan bekas galian pasir dimana kandungan hara pada lahan tersebut tidak optimal.

Nilai INP paling rendah yaitu pada tingkatan vegetasi semai atau tumbuhan bawah. Meskipun demikian, keanekaragaman tingkat pohon tidak mendominasi dari setiap plot pada ketiga wilayah pengamatan, melainkan keanekaragaman yang mendominasi ialah tingkatan vegetasi semai/tumbuhan bawah. Hal ini dijelaskan dalam penelitian Ismaini, dkk.(2015) bahwa keanekaragaman jenis tumbuhan bawah/semai merupakan indikator semakin tingginya keanekaragaman hayati pada suatu ekosistem.

Struktur pada tingkat vegetasi perintis di lahan bekas galian pasir gunung tampomas yaitu tumbuhan bawah Eleusine indica L. dan Axonopus compressus, tumbuhan semai Calliandra calothyrsus, Gliricidia sepium, Ageratum conyzoides L. Imperata cylindrica L. Saccharum spontaneum L. Vetiveria zizanioides Stapf. dan Coleus soutellarioides L. Komposisi tumbuhan perintis pada kawasan tersebut yang diperolah dari enam plot pada penelitian diantaranya terdapat 9 spesies dan genus dari 5 famili. Jumlah terbanyak yang didapatkan yaitu dari family Poaseae dengan 4 spesies dan dari family Fabaceae 2 spesies.

\section{Kondisi Iklim dan Topografi}

Tabel 6. Parameter lingkungan pada lokasi penelitian di lahan bekas galian pasir gunung tampomas

Table 6. Environmental parameters at the study site in the former sand land of tampomas mountain

\begin{tabular}{lll}
\hline No & Parameter & Kisaran \\
\hline 1 & Ketinggian tempat & $600 \mathrm{mdpl}-800 \mathrm{mdpl}$ \\
2 & Suhu & $30-32^{0} \mathrm{C}$ \\
\hline
\end{tabular}

Parameter lingkungan pada penelitian ini salah satunya ketinggian tempat 600 mdpl - 800 mdpl, dimana di kawasan ini tempat bekas galian pasir pada gunung tampomas yang sudah terdapat tumbuhan perintis.

\section{KESIMPULAN}

Struktur pada tingkat vegetasi perintis di lahan bekas galian $C$ gunung tampomas yaitu tumbuhan bawah Eleusine indica L. dan Axonopus compressus, tumbuhan semai Calliandra calothyrsus, Gliricidia sepium, Ageratum conyzoides L. Imperata cylindrica L. Saccharum spontaneum L. Vetiveria zizanioides Stapf. dan Coleus soutellarioides $L$.

Komposisi tumbuhan perintis pada kawasan tersebut yang diperolah diantaranya terdapat 9 spesies dan genus dari 5 famili. Jumlah terbanyak yang didapatkan yaitu dari family Poaseae dengan 4 spesies dan dari family Fabaceae 2 spesies. 
Parameter lingkungan pada penelitian ini salah satunya ketinggian tempat $600 \mathrm{mdpl}-800$ mdpl, dimana di kawasan ini tempat bekas galian pasir pada gunung tampomas yang sudah terdapat tumbuhan perintis.

\section{UCAPAN TERIMA KASIH}

Ucapan terimakasih kepada Kementrian Riset Teknologi dan Perguruan Tinggi yang telah memberikan bantuan dana Penelitian Dosen Pemula (PDP) pendanaan tahun 2018, LPPM UNWIM dan Fakultas Kehutanan UNWIM atas dukungannya.

\section{DAFTAR PUSTAKA}

A. Pudjiharta, Enny Widiati, Yelin Adalin, Syafrudin. 2008. Kajian Teknik Rehabilitasi Alangalang (Imperata cyilindrica L.) Info Hutan. 5(3): 221-223.

Agung Setiawan Danarto. 2013. Keragaman dan Potensi polong-polongan (Fabaseae) di Kebun Raya Perwodadi - LIPI. Seminar Nasional X Pendidikan Biologi FKIP UNS. 2-3.

F. Aulia, Darsiharjo, Jupri. 2015. Reklamasi Lahan Galian Pasir dengan Budidaya Buah Naga (Hylocereus polyrhzius) di Desa Cibereum Wetan Kecamatan Cimalaka Kabupaten Sumedang. Antologi Pendidikan Geografi 3(1): 6-10.

Fajri, M \& Garsetiasih, R. 2019. Komposisi jenis vegetasi lahan pasca tambang galian C di KHDTK Lebanan, kabupaten Berau. Jurnal Penelitian Hutan dan Konservasi Alam 16(2):101118.

Herniti, W \& Kiky, P. 2018. Variasi penutup lahan pasca penambangan pasir batu (sirtu) sebagai pembeda sifat fisik, kimia dan biologi tanah. Jurnal Rekayasa Lingkungan 18(2):110.

Ismaini Lily, Masfiro Lailati, Rustandi, Dadang Sunandar. 2015. Analisis Komposisi dan Keanekaragaman Tumbuhan di Gunung Dempo, Sumatra Selatan. Pros Sem Nas Masy Biodiv Indo. 1(6): 1400-1402.

Junaedi, A. 2008. Analisis pola perubahan pemanfaatan ruang dan implikasinya terhadap pelaksanaan rencana tata ruang wilayah kabupaten Sumedang. Thesis. Institut Pertanian Bogor.

Maulidah, S \& Brata, N.T. 2018. Struktur organisasi kerja di kalangan penambang pasir dan dampak terhadap lingkungan, ekonomi dan sosial di Segitiga pertambangan pasir. Solidarity $7(2): 448-461$.

Nursyahra, Lince Meriko. 2016. Kepadatan Vegetasi Dasar pada Lokasi Bekas Penambangan Emas di Nagari Gunung Medan Kecamatan Sitiung Kabupaten Darmasyara. BioConseta (Jurnal Biologi dan Pendidikan Biologi). 2(1): 81-82.

Suherman, D.W., Suryaningtyas, D.T., Mulatsih, S. 2015. Dampak penambangan pasir terhadap kondisi lahan dan air di kecamatan Sukaratu kabupaten Tasikmalaya. Jurnal Pengelolaan Sumberdaya Alam dan Lingkungan 5(2):99-105. 